\title{
EFFECT OF PARENT SELECTION IN APPLE SEED ROOTSTOCK BREEDING PROGRAM FOR UNIFORM TREE PRODUCTION
}

\section{Hassan Hajnajari*}

Temperate \& Cold Fruit Research Center, Horticulture Science Research Institute- Karaj, Agriculture Resreach Education \& Extension Organization, Iran

Received - December 05, 2017; Revision - February 19, 2018; Accepted - April 17, 2018

Available Online - April 25, 2018

DOI: http://dx.doi.org/10.18006/2018.6(2).396.404

\section{KEYWORDS}

Apple

Dwarf

Seed Rootstock

Genetic purity

Growth traits

Tree uniformity

\begin{abstract}
Present study was conducted in 2014-2015 to decrease genetic variability in apple seed rootstocks in order to produce trees with morphological uniformity. Effect of two different Half-Sib seed lots of "Morabbaei" was compared on 7-Year-old trees of the six apple commercial cultivars. The open pollinated seed lots were collected from selected maternal parents as two homonym Iranian native self compatible crabs "Morabbaei" characterized by different origin viz.. Isfahan and Karaj. Results of study revealed that the rootstock, graft point and trunk diameters were not significantly affected by different seed lots, scion and their interaction. The highest mean of shoot number was reported in "Red Delicious" on "Morabbaeil" seed rootstocks, for both years. Further, no significant difference was observed in case of branch angle in "Granny Smith", "Braeburn", "Gala" and "Golab-e Kohanz" grafted on the two seed lots of "Morabbaei1" and on "Morabbaei2". The highest number of lenticels was reported in "Golab-e Kohanz" on Morabbaeil seed stock, in the first year of study. All tree growth components including shoot length, shoot thickness and internode length were significantly affected at $1 \%$ level by year, rootstock and scion interaction. In general, except stable traits of the cultivars, the studied rootstocks induced similar vegetative behavior in the scions causing improved tree uniformity.
\end{abstract}

* Corresponding author

E-mail: hassanhajnajari@yahoo.com

Peer review under responsibility of Journal of Experimental Biology and Agricultural Sciences.

Production and Hosting by Horizon Publisher India [HPI] (http://www.horizonpublisherindia.in/).

All rights reserved.
All the article published by Journal of Experimental Biology and Agricultural Sciences is licensed under a Creative Commons Attribution-NonCommercial 4.0 International License Based on a work at www.jebas.org.

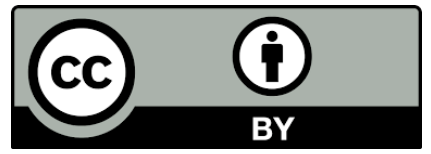




\section{Introduction}

Seed rootstocks are widely used due to easy access of seeds. Tree vigor is mainly controlled by dwarfing rootstocks which are widely employed in intensive orchards to restrict tree volume and promote earlier flowering (Barritt et al., 1995; Fallahi et al., 2002). Size-controlling rootstocks are economically important for high density apple tree plantings that may produce larger and more fruit per hectare (Autio et al., 2000; Webster \& Wertheim, 2003). Improved fruiting from size-controlling rootstocks has been accompanied by altered tree morphology associated with modification of dry weight distribution, rate and duration of shoot elongation and branch angle (Schechter et al., 1991; Strong \& Miller-Azarenko, 1991; Warner, 1991; Webster \& Wertheim, 2003). Mizani \& Hajnajari (2013) reported higher values of internode number and length in the cultivars on MM111 than other rootstocks. Despite the expansion of clonal rootstocks, seedling rootstocks continue play a pivotal role in apple seedlings production in many countries. Grafted trees on seedling rootstocks are very vigorous but diverse and are produced easily at a low cost (Webster, 1995). Apple rootstocks vary in their adaptation to soil and climatic conditions, resistance to diseases and tree size and vigor (Anderson et al., 1984; Ferree \& Warrington 2003). Except high genetic variability in seed stocks which peculiarity induces various size of tree, researchers cannot neglect the beneficiary attitudes of the seed stocks. In species such as apple, where viruses are not transmitted through seed while clonal rootstocks are significantly affected by virus, seedling rootstocks may have clear benefits. Seedling propagation also offers potential for avoiding transmission of root-borne diseases such as crown gall (Agrobacterium tumefaciens). Rootstock liners from infected stool or layer beds frequently transfer this troublesome disease to the new scion tree and to the new site. Seedling stocks raised in soils free of crown gall avoid this problem (Webster \& Wertheim, 2003; Mizani \& Hajnajari. 2013). Conditions like fragmented orchards, less adapt topography, high slope of mountainous zone, dry conditions, heavy texture, poor organic matter soils, high percentage of lime and alkali nature of soil are the factors which is inhibiting development of clonal stocks. East Malling breeders have identified two self-compatible "Delicious" and "Antonovka" with American origin and Eastern Europe, respectively and "Bittenfelder" from Western Europe as the main source of apple seed source, while in the world other cultivars are used to produce apple seeds (Webster \& Wertheim, 2003). Iranian seed market, in absence of specialized seed industry sector is forced to recycle the seeds in the wastes of processing industry for the production of apple seedling rootstocks. Use of such saplings by nurserymen is led to produce non-uniform apple trees, very vigorous with long juvenile period. To get rid of such emblematic situation, through a breeding program for apple seed stock improvement, a preliminary multiannual evaluation was achieved on the 108 cultivars and promising genotypes of the National Apple Collection (Hajnajari \& Tarrahi, 2009; Hajnajari, 2010). To select the proper parents as seed source, the cultivars were classified by tree vigor and were selected weakest cultivars adapted to Iranian soils (Hajnajari et al., 2012). Ulterior researches in 7 Year selfpollination treatments of the 108 apple cultivars let to select some completely self-compatible cultivars including also the crab apple "Morabbaei" (Hajnajari \& Moradi, 2014). It was thought that using self compatible parents distinct by genetic capacity of inbreeding could give place to weak vigor seeds capable to control tree size and inducing contemporaneously more uniformity to the grafted scions, due to existing relative genetic purity, in the other worlds seeds with less genetic variability. In another breeding program, "Morabbaei" was selected as one of the most important maternal parents for the production of clonal rootstocks resistant to crown rot (Soroori et al., 2010). The purpose of this study was to ascertain efficiency of the selected maternal parent cultivar with two geographical origins for producing high quality seed rootstocks marked by increased genetic purity and eventual differences between the two ecotypes. The trial was achieved to investigate the effect of probable different origin of the chance seedlings crab apple "Morabbaei" grown in two distant geographical zones, Isfahan and Karaj. So, to eliminate any doubts about the genetic variation of parent trees "Morabbaei", six commercial cultivars, grafted on the two self-compatible seed lots of "Morabbaei1" and "Morabbaei2" with origins, of Karaj and Isfahan respectively. The proper parent selection in breeding program is a crucial pass depending on the target, here as inductive effect of seed lots on tree morphological uniformity.

\section{Materials and Methods}

\subsection{Plant material, experimental design, sample collection}

Half-Sib seed lots were collected from open pollinated fruits of Iranian native crab apple "Morabbaei" in a breeding program for seed rootstock improvement. Crab cv. Morabbaei trees as maternal parent, grown in Isfahan and Karaj regions, being from two different origins could be probably two ecotypes and not surely True-To-Type. Complementary multiannual field selfpollinations and laboratory researches by Fluorescent microscope in Karaj confirmed "Morabbaei1" completely as self-compatible cultivar. In present biennial experiment, 6 to 7-Year-old trees grafted on the two seed lots, Morabbaei1 and Morabbaei2, consisted of six commercial apples "Golden Delicious", "Red Delicious", "Granny Smith", "Braeburn", "Gala"and early native "Golab-e Kohanz". The experimental orchard is established in Meshgin Abad station under Cold \& Temperate Fruit research Center located in Karaj, Alborz province-Iran. Six trees were assigned for each $\mathrm{Cv}$-Seed lot combination enough large to explain seed source inductive effect. The trees were planted in 
distances of $3 \times 3 \mathrm{~m}$, pruned in Spindle with lateral branches spread on the leader within them four were labeled on each tree for growth assessments and data collection. The randomized complete block (RCBD) design with six replications was used for statistical analysis.

\subsection{Agromorphological characteristics}

In the present study, growth traits of grafted scions were measured at the end of the two successive vegetative seasons of 2014-2015. Dwarfing effects of the two seed lots interacting with scion tree vigor reflected in growth traits of the grafted cultivars were measured.

\subsubsection{Rootstock, graft point and trunk diameters}

Rootstock diameter $10 \mathrm{~cm}$ above the earth, graft union diameter and trunk diameter $10 \mathrm{~cm}$ above the graft union were measured in each rootstock-scion combination by caliper at the end of growth season.

\subsubsection{Shoot number}

The number of shoots per tree were counted visually and registered, late in September.

\subsubsection{Branch angle}

Crotch angle from the trunk of three main architectural branches per tree was measured and expressed in apple descriptor.

\subsubsection{Lenticels number}

The number of lenticels within two internodes of annual branches were counted visually and scored using standardized index of apple descriptor.

\subsubsection{Number and length of internodes}

Six annual shoots were selected in different directions from the middle part of each tree and the number of internodes were counted and recorded. The length of the internodes was measured by the caliper after identifying the annual branches.

\subsubsection{Shoot length and thickness}

The growth of 10 shoots per tree from the previous season (length and number of internodes) was measured and recorded. The diameter of the middle section of annual branches was accurately measured by the caliper.

\subsection{Statistical analysis}

Analysis of variance was performed by combined analysis using the collected data regarding all growth traits in examination of both seed rootstocks and cultivars. All statistical analyses were undertaken using the general linear model (GLM) procedure of the SAS version 9.0. The Duncan multiple range test $(P \leq 0.01)$ was used to evaluate differences between treatments.

\section{Results}

\subsection{Root, Graft and Trunk Diameter}

According to the data analysis (Table 1), the rootstock, graft and trunk diameters of the studied trees were affected by year factor and there were no significant variation among trees regarding rootstock, scion and their interactions. In the second year, three diameter values of rootstock, scion and graft point were resulted higher than the first year (Figure 1, 2 and 3).

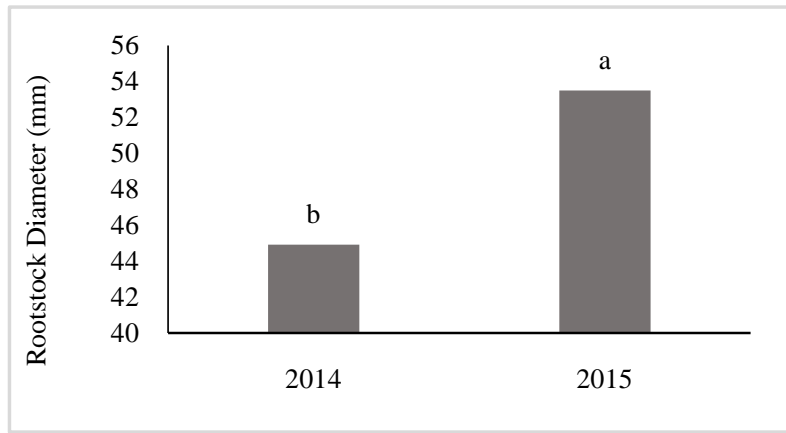

Figure 1 Effect of the year on rootstock diameters of scion cultivars (Means with similar letters are not significantly different at the $1 \%$ probably level using Duncan multiple range test)

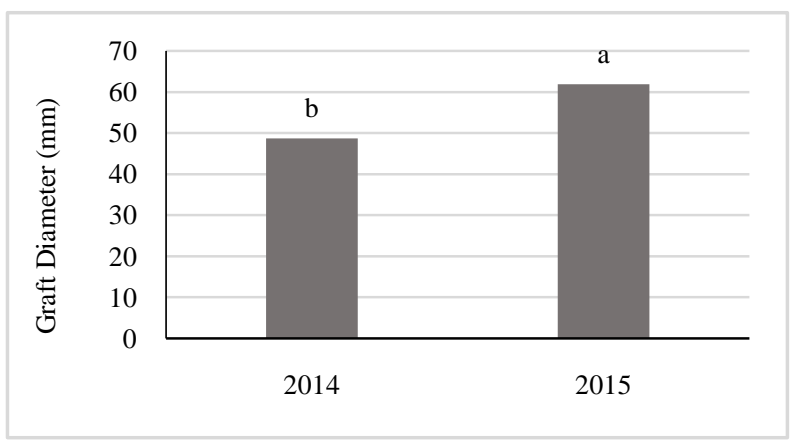

Figure 2 Effect of the year on graft diameters of scion trees (Means with similar letters are not significantly different at the 1\% probably level using Duncan multiple range test)

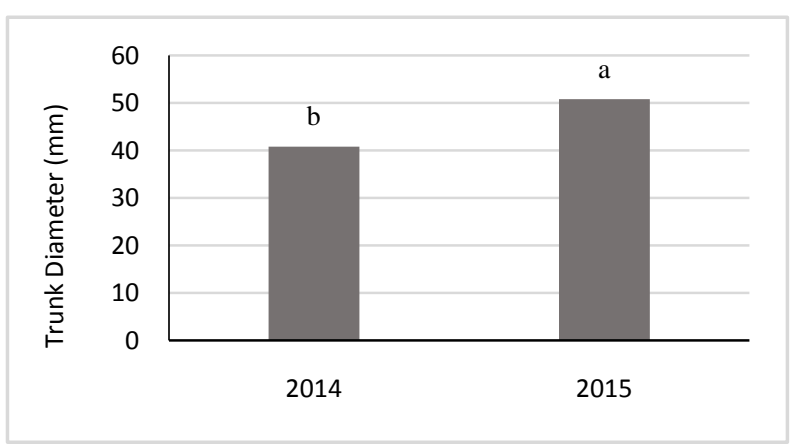

Figure 3 Effect of the year on trunk diameters of the scion trees (Means with similar letters are not significantly different at the $1 \%$ probably level using Duncan multiple range test) 
Table 1 Analysis of variance of the year, rootstock and scion effects on some growth traits

\begin{tabular}{|c|c|ccccc|}
\hline & & \multicolumn{3}{c}{ Mean Square } \\
Source & DF & Rootstock & $\begin{array}{c}\text { Graft } \\
\text { Diameter }\end{array}$ & $\begin{array}{c}\text { Trunk } \\
\text { Diameter }\end{array}$ & $\begin{array}{c}\text { Shoot } \\
\text { number }\end{array}$ & $\begin{array}{c}\text { Branch } \\
\text { Angle }\end{array}$ \\
\hline Year & 1 & $1204.15^{* *}$ & $4115.95^{* *}$ & $2025.16^{* *}$ & $32.11^{*}$ & $624.28^{\text {ns }}$ \\
\hline Block(year) & 10 & $36.92^{\text {ns }}$ & $104.12^{\text {ns }}$ & $136.34^{\text {ns }}$ & $21.93^{* *}$ & $120.50^{\text {ns }}$ \\
\hline Rootstock & 1 & $48.66^{\text {ns }}$ & $79.03^{\text {ns }}$ & $89.74^{\text {ns }}$ & $10.02^{\text {ns }}$ & $1201.75^{*}$ \\
\hline Scion & 5 & $86.11^{\text {ns }}$ & $12.09^{\text {ns }}$ & $130.60^{\text {ns }}$ & $88.41^{* *}$ & $184.09^{\text {ns }}$ \\
\hline Rootstock $\times$ Scion & 5 & $217.47^{\text {ns }}$ & $194.90^{\text {ns }}$ & $154.69^{\text {ns }}$ & $90.69^{* *}$ & $931.83^{* *}$ \\
\hline Year $\times$ Rootstock & 1 & $108.27^{\text {ns }}$ & $2.80^{\text {ns }}$ & $227.89^{\text {ns }}$ & $18.77^{\text {ns }}$ & $44.69^{\text {ns }}$ \\
\hline Year $\times$ Scion & 5 & $47.52^{\text {ns }}$ & $68.98^{\text {ns }}$ & $50.21^{\text {ns }}$ & $14.34^{\text {ns }}$ & $191.84^{\text {ns }}$ \\
\hline Year $\times$ Rootstock $\times$ Scion & 5 & $34.52^{\text {ns }}$ & $47.78^{\text {ns }}$ & $17.05^{\text {ns }}$ & $21.71^{*}$ & $154.23^{\text {ns }}$ \\
\hline Error & 110 & 117.53 & 136.07 & 119.66 & 8.10 & 207.36 \\
\hline CV(\%) & & 22.27 & 21.19 & 23.84 & 27.66 & 18.57 \\
\hline
\end{tabular}

The P-value for each trait is indicated with its significance (ns, non-significant; *, P, 0.05; **, P, 0.01).

\subsection{Shoot number}

Grafting period, rootstock and scion interaction significantly affected (at 1\%) shoot number per tree (Table 1). According to the results (Table 2), "Red Delicious" on "Morabbaei1" showed the highest number of branches, in each year of this study and "Golab-e Kohanz" on "Morabbaei1" showed the lowest value, in 2014.

\subsection{Branch Angle}

According to the results of variance analysis, branch angle was affected by rootstock and scion $\times$ rootstock interaction (Table 1 ). The highest branch angle was observed in Red Delicious on Morabbaei1 while the lowest branch angle was observed in Golden Delicious on Morabbaei2 (Table 3).

\subsection{Lenticels Number}

The effect of year, rootstock and scion were significant concerning lenticels number as a relatively stable trait (Table 4). The highest number of lenticels was found in "Golab-e Kohanz" on "Morabbaei1" seeds in the first year of study (Table 2). According to table 2, the grafted cultivars on "Morabbaei1" and "Morabbaei2" did not differ much from each other, in the both years.

In the first year, "Red Delicious" on "Morabbaei1" seeds had no significant difference with "Red Delicious" on Morabbaei2, but other grafted cultivars showed significant variation on different rootstocks. In the second year, "Golden Delicious", "Granny Smith" and "Gala" didn't show significant differences (Table 2).

\subsection{Shoot Length and Thickness, Internode Number and} Length

\subsubsection{Shoot Length and Thickness}

All growth components including shoot length, shoot thickness, internode number and internode length were affected significantly at $1 \%$ level in a normal trend of annual tree growth physiology. Shoot length differed significantly by scion at $1 \%$ of probability considering different genetic tree vigor. The same level of significance was observed in the interaction of rootstock $\times$ scion and year×rootstock on shoot length and shoot thickness. The highest values of shoot length and thickness were found in "Red Delicious" on "Morabbaei1" seeds in the first year.

\subsubsection{Internode Number and Length}

Like other parameters internode number was also affected by year factor. The internode number was higher in the first year (2014) and this was followed by second year (Figure 4). Further, data analysis (Table 4) also suggested that internode length was affected by year, rootstock and scion interactions. In 2014, "Red Delicious" on "Morabbaei1" seed lot demonstrated the highest size of internode length and "Gala" on "Morabbaei2" had the lowest value, in 2015 (Table 2).

In general, the grafted cultivars on "Morabbaei1" and "Morabbaei2" did not differ significantly regarding Internode length. Rootstock origin had no effect on the internode length of the each cultivar separately, in the first year, whereas in the second year the internode length of "Golden Delicious", "Red 
Table 2 Interaction effect of year×scion $\times$ rootstock on some growth traits

\begin{tabular}{|c|c|c|c|c|c|c|c|}
\hline $\begin{array}{l}\varangle \\
\stackrel{8}{a}\end{array}$ & $\begin{array}{l}\text { Seed } \\
\text { Stock }\end{array}$ & Scion & Shoot Number & Shoot Length & $\begin{array}{c}\text { Shoot } \\
\text { Thickness }\end{array}$ & $\begin{array}{l}\text { Internode } \\
\text { Length }\end{array}$ & $\begin{array}{c}\text { Lenticels } \\
\text { Number }\end{array}$ \\
\hline \multirow{12}{*}{$\underset{\infty}{\stackrel{N}{D}}$} & \multirow{6}{*}{ 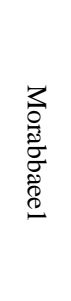 } & "Golden Delicious" & $14.50^{\mathrm{b}}$ & $193.63^{\text {ab }}$ & $6.18^{\mathrm{b}}$ & $16.83^{\mathrm{bc}}$ & $21.21^{\mathrm{bc}}$ \\
\hline & & "Red Delicious" & $17.17^{\mathrm{a}}$ & $195.06^{\mathrm{a}}$ & $8.00^{\mathrm{a}}$ & $20.33^{\mathrm{a}}$ & $21.94^{\mathrm{bc}}$ \\
\hline & & "Granny Smith" & $13.00^{\mathrm{bc}}$ & $174.61^{\mathrm{d}}$ & $6.36^{\mathrm{b}}$ & $13.73^{\mathrm{de}}$ & $21.40^{\mathrm{bc}}$ \\
\hline & & "Braeburn" & $9.33^{\mathrm{d}}$ & $159.70^{\mathrm{f}}$ & $7.63^{\mathrm{ab}}$ & $15.75^{\mathrm{c}}$ & $23.80^{\mathrm{b}}$ \\
\hline & & "Golab-e Kohanz" & $6.33^{\mathrm{f}}$ & $165.74^{\mathrm{ef}}$ & $7.41^{\mathrm{ab}}$ & $15.30^{\mathrm{cd}}$ & $29.26^{\mathrm{a}}$ \\
\hline & & "Gala" & $8.00^{\mathrm{de}}$ & $177.20^{\text {cd }}$ & $7.86^{\mathrm{a}}$ & $15.03^{\mathrm{cd}}$ & $15.50^{\mathrm{e}}$ \\
\hline & \multirow{6}{*}{ 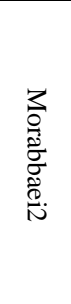 } & "Golden Delicious" & $8.67^{\mathrm{de}}$ & $177.5^{\mathrm{cd}}$ & $5.83^{\mathrm{bc}}$ & $15.80^{\mathrm{c}}$ & $14.27^{\text {ef }}$ \\
\hline & & "Red Delicious" & $11.83^{\mathrm{c}}$ & $185.18^{\mathrm{bc}}$ & $5.91^{\mathrm{bc}}$ & $17.61^{\mathrm{b}}$ & $20.33^{c}$ \\
\hline & & "Granny Smith" & $11.17^{\mathrm{c}}$ & $169.69^{\mathrm{e}}$ & $5.77^{\mathrm{bc}}$ & $16.90^{\mathrm{bc}}$ & $26.75^{\mathrm{ab}}$ \\
\hline & & "Braeburn" & $11.17^{\mathrm{c}}$ & $158.07^{\mathrm{f}}$ & $7.12^{\mathrm{ab}}$ & $12.16^{\mathrm{e}}$ & $12.62^{\mathrm{g}}$ \\
\hline & & "Golab-e Kohanz" & $9.33^{\mathrm{d}}$ & $168.75^{\mathrm{e}}$ & $5.58^{\mathrm{bc}}$ & $16.03^{\mathrm{c}}$ & $20.11^{c}$ \\
\hline & & "Gala" & $8.67^{\mathrm{de}}$ & $179.53^{\mathrm{c}}$ & $6.02^{\mathrm{b}}$ & $16.50^{\mathrm{bc}}$ & $25.06^{\mathrm{ab}}$ \\
\hline \multirow{12}{*}{$\frac{N}{\stackrel{n}{r}}$} & \multirow{6}{*}{$\begin{array}{l}3 \\
3 \\
0 \\
\tilde{0} \\
\tilde{0} \\
\stackrel{0}{0} .\end{array}$} & "Golden Delicious" & $10.00^{\mathrm{cd}}$ & $143.23^{\mathrm{h}}$ & $6.08^{\mathrm{b}}$ & $14.66^{\mathrm{d}}$ & $21.08^{\mathrm{bc}}$ \\
\hline & & "Red Delicious" & $17.17^{\mathrm{a}}$ & $193.18^{\mathrm{ab}}$ & $4.33^{\mathrm{de}}$ & $21.24^{\mathrm{a}}$ & $22.63^{b}$ \\
\hline & & "Granny Smith" & $7.33^{\mathrm{e}}$ & $114.23^{\mathrm{i}}$ & $4.63^{\mathrm{d}}$ & $13.78^{\mathrm{de}}$ & $17.43^{\mathrm{d}}$ \\
\hline & & "Braeburn" & $6.67^{\mathrm{f}}$ & $151.71^{\mathrm{g}}$ & $4.68^{\mathrm{d}}$ & $16.78^{\mathrm{bc}}$ & $23.19^{b}$ \\
\hline & & "Golab-e Kohanz" & $7.83^{\mathrm{e}}$ & $156.16^{\mathrm{f}}$ & $4.96^{\mathrm{cd}}$ & $15.61^{\mathrm{c}}$ & $19.93^{\mathrm{c}}$ \\
\hline & & "Gala" & $9.33^{\mathrm{d}}$ & $150.88^{\mathrm{g}}$ & $5.24^{\mathrm{c}}$ & $11.50^{\mathrm{ef}}$ & $17.50^{\mathrm{d}}$ \\
\hline & \multirow{6}{*}{ 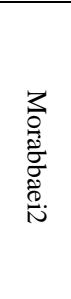 } & "Golden Delicious" & $9.83^{\mathrm{d}}$ & $188.39^{\mathrm{b}}$ & $4.94^{\mathrm{cd}}$ & $10.25^{\mathrm{f}}$ & $17.77^{\mathrm{d}}$ \\
\hline & & "Red Delicious" & $8.50^{\mathrm{de}}$ & $163.74^{\text {ef }}$ & $4.10^{\mathrm{e}}$ & $10.08^{\mathrm{f}}$ & $13.97^{\mathrm{f}}$ \\
\hline & & "Granny Smith" & $10.67^{\mathrm{cd}}$ & $173.28^{\mathrm{d}}$ & $4.33^{\mathrm{de}}$ & $8.89^{\mathrm{g}}$ & $16.50^{\mathrm{de}}$ \\
\hline & & "Braeburn" & $12.00^{\mathrm{bc}}$ & $152.23^{\mathrm{g}}$ & $4.79^{\mathrm{cd}}$ & $10.44^{\mathrm{f}}$ & $17.70^{\mathrm{d}}$ \\
\hline & & "Golab-e Kohanz" & $9.67^{\mathrm{d}}$ & $143.72^{\mathrm{h}}$ & $3.86^{\mathrm{f}}$ & $9.89^{\mathrm{fg}}$ & $15.50^{\mathrm{e}}$ \\
\hline & & "Gala" & $8.83^{\mathrm{de}}$ & $179.31^{\mathrm{c}}$ & $4.83^{\mathrm{cd}}$ & $8.64^{g}$ & $16.68^{\mathrm{de}}$ \\
\hline
\end{tabular}

Means, with similar letters are not significantly different at the 1\% probably level using Duncan multiple range test.

Table 3 Interaction effect of rootstock $\times$ scion on branch angle

\begin{tabular}{|c|c|c|}
\hline Rootstock & Scion & Branch Angle \\
\hline \multirow{6}{*}{ "Morabbaee1" } & "Golden Delicious" & $86.08^{\mathrm{ab}}$ \\
\hline & "Red Delicious" & $95.00^{\mathrm{a}}$ \\
\hline & "Granny Smith" & $87.5^{\mathrm{ab}}$ \\
\hline & "Braeburn" & $69.09^{d}$ \\
\hline & "Golab-e Kohanz" & $77.91^{\mathrm{bc}}$ \\
\hline & "Gala" & $78.33^{\mathrm{bc}}$ \\
\hline \multirow{6}{*}{ "Morabbaee2" } & "Golden Delicious" & $65.00^{\mathrm{e}}$ \\
\hline & "Red Delicious" & $73.33^{\mathrm{c}}$ \\
\hline & "Granny Smith" & $71.25^{\mathrm{c}}$ \\
\hline & "Braeburn" & $78.75^{\mathrm{bc}}$ \\
\hline & "Golab-e Kohanz" & $80.83^{\mathrm{b}}$ \\
\hline & "Gala" & $81.66^{\mathrm{b}}$ \\
\hline
\end{tabular}

Journal of Experimental Biology and Agriculture Science http://www.jebas.org 
Table 4 Analysis of variances of year, rootstock and scion effects on some growth traits

\begin{tabular}{|c|c|c|c|c|c|c|}
\hline \multirow[b]{2}{*}{ Source } & \multirow[b]{2}{*}{ DF } & \multicolumn{5}{|c|}{ Mean Square } \\
\hline & & $\begin{array}{c}\text { Lenticels } \\
\text { Number }\end{array}$ & Shoot Length & $\begin{array}{c}\text { Shoot } \\
\text { Thickness }\end{array}$ & $\begin{array}{l}\text { Internode } \\
\text { Number }\end{array}$ & Internode Length \\
\hline Year & 1 & $1359.52^{* *}$ & $48827.93^{* *}$ & $626.11^{* *}$ & $12207.56^{* *}$ & $1839.88^{* *}$ \\
\hline Block Years & 10 & $81.12^{\mathrm{ns}}$ & $3665.72^{\mathrm{ns}}$ & $3.41^{* *}$ & $250.29^{\mathrm{ns}}$ & $24.94^{\mathrm{ns}}$ \\
\hline Rootstock & 1 & $1746.68^{* *}$ & $4685.13^{\mathrm{ns}}$ & $110.08^{* *}$ & $712.47^{\mathrm{ns}}$ & $1577.96^{* *}$ \\
\hline Scion & 5 & $135.79^{*}$ & $16131.82^{* *}$ & $12.73^{* *}$ & $457.80^{\mathrm{ns}}$ & $177.90^{* *}$ \\
\hline Rootstock $\times$ Scion & 5 & $848.70^{* *}$ & $8957.26^{* * *}$ & $6.83^{* *}$ & $308.86^{\mathrm{ns}}$ & $133.53^{* *}$ \\
\hline Year $\times$ Rootstock & 1 & $108.65^{\mathrm{ns}}$ & $17227.02^{* *}$ & $24.01^{* *}$ & $60.86^{\mathrm{ns}}$ & $1260.69^{* *}$ \\
\hline Year $\times$ Scion & 5 & $512.01^{* *}$ & $1555.37^{\mathrm{ns}}$ & $20.51^{* *}$ & $410.99^{\mathrm{ns}}$ & $100.11^{\text {** }}$ \\
\hline Year $\times$ Rootstock $\times$ Scion & 5 & $377.53^{* *}$ & $10755.98^{* *}$ & $6.72^{* *}$ & $205.25^{\mathrm{ns}}$ & $38.37^{*}$ \\
\hline Error & 110 & 49.72 & 2112.70 & 1.10 & 267.32 & 14.71 \\
\hline $\mathrm{CV}(\%)$ & & 25.42 & 27.40 & 18.21 & 28.21 & 27.54 \\
\hline
\end{tabular}

The P-value for each trait is indicated with its significance (ns, non-significant; *, P, 0.05; **, P, 0.01 ).

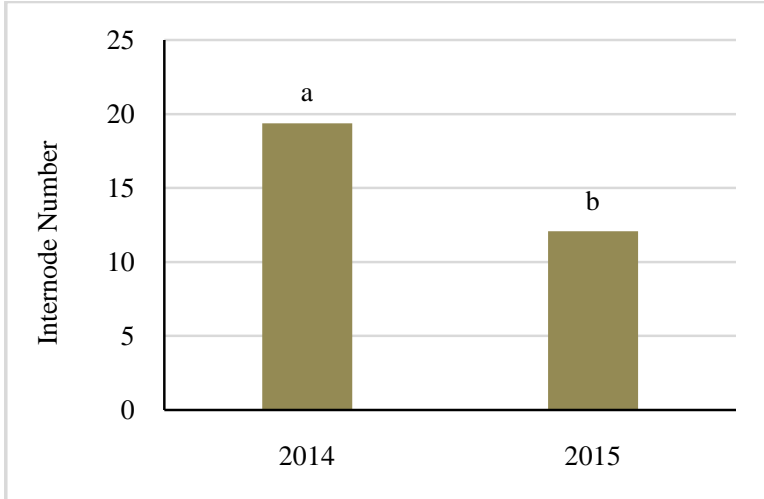

Figure 4 Effect of year on internode number of scion trees (Means with similar letters are not significantly different at the $1 \%$ probably level using Duncan multiple range test)

Delicious", "Granny Smith" and "Gala" were differed significantly based on origin (Table 2). Comparing two successive years, it was reported that internode length of all the grafted cultivars on "Morabbaeil" seeds in the first year had not significant difference with it in the second year, whereas the grafted cultivars on "Morabbaei2" had higher internode length in the first year than the second year (Table 2).

\section{Discussion}

Lack of variation among trees trunk diametric growth at three key points reinforces the effect of relative genetic purity of the improved seed rootstocks. It may be interpreted also as an external sign of similar internal rootstocks-scions hormonal balance. Surprisingly, no significant differences were observed in interactions between rootstock $\times$ scion, year $\times$ rootstock and year×scion. Contrary to the current results, Jobir (2016) studying the effect of clonal stocks MM106 and M26 on morphological characteristics of "Crispin" and "Granny Smith" reported the significant effect of rootstocks on trunk diameters. These results demonstrate existence of high morphological uniformity of the studied vegetative traits of scion trees due to homogenous induction of both seed lots and clonal rootstocks, meaning uniform inductive effect of "Morabbaei" seed stocks. The attained morphological uniformity of the scion trees is due to the genetic purity carried by seed lots produced by self-compatible maternal parents. The diameter of trunk, rootstock and graft point increased in the second year, which is related to natural trend of annual tree growth.

Tree growth and development can be markedly influenced by both cultivar and rootstock (Hirst \& Ferree, 1995). In agreement with previous results, rootstocks had significant effect on number of shoots of apple scions (Tahereh et al. 2011; Jobir, 2016). Results of study revealed that "Red Delicious" on Morabbaei1 seed rootstocks, in both years, had the highest mean shoot number while "Golab-e Kohanz" had the lowest value, in the first year. It confirms role of tree vigor by itself, at least for this trait as one of the growth components.

As per the results, significant variation was reported among the grafted cultivars on "Morabbaei1" seeds regarding shoot number in 2014 while next year, only "Red Delicious" showed a significant difference compared to other cultivars.

In case of the "Morabbaei2" seed rootstocks, in the first year, no significant difference was observed among the studied cultivars, 
whereas in the second year, there was significant variation between "Red Delicious" and "Braeburn".

As per results, all the studied cultivars grafted on the seeds of parent "Morabbaei1" of Karaj origin produced more branches than the same cultivar on "Morabbaei2" known as Isfahan origin. The difference between the two seed lots of rootstocks with different origin "Morabbaei" is probably due to the genetic factor derived from maternal effect meaning probable presence of two "Morabbaei" clones from a major cultivar firstly, or the diverse nutritional management of "Morabbaei2" parent rather than "Morabbaei1" in different pedo-climatic conditions (Ghanbarloo \& Hajnajari, 2013). Even the self-compatible cultivars enjoy reception of foreign pollen, resulting in a better fruit set, the main reason for use of certain pollinizers distinct by different pollen production potential in apple orchards. However, more fertilized stigmas will lead to higher seed number and fruit set (Wertheim \& Schmidt. 2005). Seed orchard however should be established based on specific normative e.g. far from apple orchards, therefore mainly different to normal fruit orchards (Hajnajari, 2016).

On the other hand, the individual grafted cultivars on "Morabbaei1" didn't show significant differences with the same cultivar on "Morabbaei2" in terms of number of branches, except "Red Delicious" that in both years was different on "Morabbaei1" compared to "Morabbaei2" (table 2). It can be concluded that use of self-compatibile parent "Morabbaei" as seed source has induced similar vegetative behavior in the grafted cultivars (Ghanbarloo \& Hajnajari, 2013). So, in rootstock breeding program, parent selection plays vital role based on the target. In this case besides other characteristics other key traits as dwarfism and self-compatibility were determinant in induction of trees size uniformity as well.

Certain traits including branch angle, lenticels size, and lenticels number even slightly affected by rootstock, genetically are considered as stable traits or less prone to variation (Hajnajari et al., 2008). In general terms, result of present study were confirmed considering the genetic principle of stability of scion traits in most of the grafted cultivars on each seed source rootstock separately, where no significant difference was noted. Few instability cases were noticed in rootstock and scion interaction, for example "Red Delicious" on"Morabbaei1" had the highest angle and "Golden Delicious" on "Morabbaei2" was marked by the lowest value (Table 3). The latter registered differences may be attributed partly to the effect of Spindle pruning. Very positive response was obtained as the result of minimum variation of inductive effect into the vegetative traits of grafted scions by improved inbred seeds in this breeding program. There was not observed significant differences between "Granny Smith", "Braeburn", "Gala" and "Golab-e Kohanz" on "Morabbaei1" seed lot related to the same cultivars grafted all on
"Morabbaei2" seed lot, as the most diffused commercial apple cultivars in exam (Table 3). The criteria assumed for parent selection as self-compatibility and dwarfness both together in seed rootstock breeding was the key to achieve such result. The opted native crab apples as the maternal parents improved seed quality through decreasing genetic variability as the seed rootstock breeding pathway.

In the first year, "Golab-e Kohanz" on "Morabbaei1" showed the highest number of lenticels. The reason very probably is hidden in the high tree vigor of this Iranian cultivar. Vigorous trees with high transpiration rate need more stomata to respond vital functions present in the big canopy size, $35 \mathrm{~m}^{2}$ of the shaded area, in 14-Year-old trees.

While shoot length was not affected by rootstock as a sign of growth deceleration, the shoot thickness showed significant difference at $1 \%$ level meaning that a simultaneous diametric growth where the carbohydrate are accumulated for productive activities. Similar mechanism of growth control showed by seed offspring in the present research is known in dwarfing clonal rootstocks as M27 and/or p22. During two successive years, 2014 and 2015, no significant variation in shoot length was observed among cultivars grafted on "Morabbaei1" and on "Morabbaei2" (Table 2). The element that strengthens efficiency of the improved seed lots for production of uniform apple trees. In 2014, "Golden Delicious" and "Granny Smith" both showed significant difference for shoot thickness compared with other cultivars on "Morabbaei1" and in 2015, "Golden Delicious" on "Morabbaei1" showed significant variations with other combinations. In the first year, the grafted cultivars on "Morabbaei2" seeds didn't show significant variation, but in the second year shoot thickness of the cultivars grafted on "Morabbaei2" were significantly different.

The internode number was higher for the first year. It can be attributed also to the difference between orchard management during two years and more rainfall during 2014. Generally, the studied rootstocks induced similar vegetative behavior in the scions and minor differences between some combinations can be attributed to the hormone interaction of the rootstock and the scion. The assumption is that, rootstock, or possibly its graft union alters the ratios and concentrations of the growth promoting and may also inhibiting hormones which are translocated within the tree (Ferree \& Warrington, 2003; Michael, 2009). There is rare information in literature on mechanism of dwarfing systems. In a better said we are not aware of complex pathways of fruit plant biology as the interface between responsible genes for plant growth regulators biosynthesis and also the direct responsible genes for dwarfing plants. As the results shown, tree growth was higher in 2014 than 2015. It can be related to better nutrition and irrigation conditions in the first year or different climatic conditions during 2014 and 2015. As Foster et al. (2016) reported 
that rootstock-induced dwarfing exhibits a high degree of plasticity in response to growing environment, growing season and the type of scion bud grafted. Understanding that these factors can profoundly modify young tree vigor and architecture is highly relevant to both growers and rootstock breeders.

The significant differences observed among the studied growth and vegetative traits of the six cultivars on two seed lots during two consecutive years is quite natural in plant growth trend. Use of such maternal parents as source of seed rootstocks not only will discard need of pollinizers in seed orchard leading to produce pure genetic offspring by which nurserymen can successfully produce apple trees capable to control canopy size, tree structure and vegetative growth. Such trees make possible to increase number of tree per unit of area, from 320 to 900 , based also on scion vigor. The tree uniformity facilitate all orchard practices as pruning, fertilizer and pesticide sprays and harvest particularly where for any reason clonal stocks many not be used.

\section{Conclusion}

It was confirmed that decreasing genetic variability is the first essential pass to produce seed rootstock. To reach the target, severe evaluation of the available germplasm is also needed in the parent selection. So, it needs drastic decrease of seed source cultivars and at the same time searching those parents with very particular traits like adaptability to regional pedo-climatic conditions, weak vigor, high bloom intensity, elevate fruit and seed set potential, tolerant to leaf chlorosis and either selfcompatibility. Limited number of parents facilitates produce of seeds with high genetic purity, the objective that will lead the apple tree production toward ideal uniformity near to those of clonal rootstocks. The pure seeds produced by weak vigor parents even smaller in size but they are able to induce this trait also to the grafted scions. To ascertain seed purity, seed orchard management standards are essential to be safeguarded. In this experiment, use of a native crab adapt to typical Iranian soils "Morabbaei" characterized by dwarf growth indeed self-compatibility feature provided access to uniform seeds with low vigor. Satisfactory use of such seeds in apple tree production is confirmed by the results shown this trial by in increased uniformity of very common cultivars in growth parameters like tree size and growth habit of the grafted trees.

\section{Conflict of Interest}

Authors would hereby like to declare that there is no conflict of interests that could possibly arise.

\section{References}

Anderson PC, Lombard PB, Westwood MN (1984) Leaf conductance, growth, and survival of willow and deciduous fruit tree species under flooded soil conditions. Journal of the American Society for Horticultural Science 109: 132-138.

Autio WR, Krupa J, Clements J (2000) Performance of trees in the Massachusetts planting of the 1994 NC-140 apple rootstock trial over seven growing seasons. Fruit Notes 65: 1-3.

Barritt BH, Konishi BS, Dilley MA (1995) Performance of 3 apple cultivars with 23 dwarfing rootstocks during 8 seasons in Washington. Fruit Cultivars Journal 49: 158-70.

Fallahi E, Colt WM, Fallahi B, Chun I (2002) The importance of apple rootstocks on tree growth, yield, fruit quality, leaf nutrition and photosynthesis with an emphasis on 'Fuji'. Horticulture Technology. 12: 38-44.

Ferree DC, Warrington IJ (2003) Apples: Botany, Production and Uses. Ohio State University, USA, I Warrington, Horticulture Research, New Zealand. 672 pages; Publisher: CABI.

Foster TM, Hooijdonk BMV, Friend AM, Seleznyova AN, McLachlan ARG (2016) Apple rootstock-induced dwarfing is strongly influenced by growing environment. Journal of Horticulture 3:180.

Ghanbarloo M, Hajnajari H (2013) Preliminary study on the effect of apple selected seeds produced by dwarf parents on height and canopy size of six commercial cultivars. $13^{\text {th }}$ Genetic Congress, 3 5 June, 2013, held at University of Sh. Beheshti, Tehran, Iran.

Hajnajari H, Dehghany SY, Khandan A, Lahiji MF (2008) National Guideline for the Conduct of Tests for Distinctness, Uniformity and Stability in Apple. Agriculture publication divulgation. Agriculture Research, Education and Extension organization (AREO) (In Farsi).

Hajnajari H, Soroori S, Rezaee S, Zamani Zadeh HR (2012) Iranian crab apple 'Zinati' with dual tolerance as maternal source selected for rootstock breeding. Acta Horticulturae 938: 527-534.

Hajnajari H, Moradi M (2014) Determination of Self Compatibility Levels, Physiological Disorders, Pomology of Apples and Introduction of 'IRI6' as Promising Self Compatible cultivar. Iranian Horticulture Science Journal 45: 136-174 (In Farsi).

Hajnajari H (2016) Guide of Apple Cultivation Relying on Research Achievements. Agriculture publication divulgation. Agriculture Research, Education and Extension organization (AREO) (In Farsi).

Hajnajari H (2010) Cultivar evaluation program of the national Iranian apple collection in the last decade. Proceeding of the International Scientific Conference of Fruit Growing 
Intensification in Belarus: Traditions, Progress and Prospects held on $1^{\text {st }}$ September - $1^{\text {st }}$ October, 2010 at Samokhvalovichy, Pp:3339.

Hajnajari H, Tarrahi SH (2009) Investigation on vegetative traits and growth characteristics of 16 imported commercial apple cultivars in Karaj- Iran climatic conditions. Innovative technologies in nursery management and rootstock research. Proceeding of International Scientific Conference held on June, 15 - July, 31, 2009 at Samokhvalovichy Belarus.

Hirst PM, Ferree DC (1995) Effect of rootstock and cultivar on the growth and precocity of young apple tree. Journal American Society of Horticulture Sciences. 120: 622-634.

Jobir K (2016) Effects of MM. 106 and M. 26 Rootstocks on Agromorphological Characteristics of 'Crispin' and 'Granny Smith' Apple Cultivars in Chencha, Southern Ethiopia. IOSR Journal of Pharmaceutical Biology Sciences 11: 7-10.

Michael BH (2009) The physiological basis of vigour control by apple rootstocks-on unresolved paradigm. New Zealand, Palmerstone North: Massey University.

Mizani A, Hajnajari H (2013) Detection of ApMV and TomRSV in apple trees and inhibitive effect of seed rootstocks against viral infections. International Journal of Agronomy and Plant Production 3: 554-562.

Schechter I, Elfving DC, Proctor JTZ (1991) Canopy development, photosynthesis, and vegetative growth as affected by apple rootstocks. Fruit Varieties Journal 45: 229-237.
Soroori S, Hajnajari H, Rezaee S, Zamani Zadeh HR (2010) Evaluation of apple dwarf cultivars seedlings for selection of rootstocks tolerant to Phytophthora Cactorum, causal agent of crown rot disease. Seed and Plant Improvement Journal 26: 193204 (In Farsi).

Strong D, Miller-Azarenko A (1991) Dry matter partitioning in 'Starkspur Supreme Delicious' on nine rootstocks. Fruit Varieties Journal 45: 238-241.

Tahereh P, Hossein A, Abdolghafar E (2011) A study of the influence of different rootstocks on the vegetative growth of almond cultivars. African Journal of Biotechnology 10: 1680816812.

Warner J (1991) Rootstock affects primary scaffold branch crotch angle of apple trees. Horticultural Science (HortScience). 26: $1266-1267$.

Webster AD (1995) Temperate fruit tree rootstock propagation. New Zealand Journal of Crop and Horticultural Science 23: 355372.

Webster AD, Wertheim SJ (2003) Apple rootstocks. In: Ferree DC, Warrington IJ (Eds.), Apples: Botany, Production and Uses. CAB International, Cambridge, MA, Pp. 91-124.

Wertheim SJ, Schmidt H, (2005) Flowering, pollination and fruit set. In: Tromp J, Webster AD, Wertheim SJ (Eds.) Fundamentals of Temperate Zone Tree Fruit Production, Baskhuys publishers, Leiden. The Netherlands. 